\title{
EVALUATION OF ANTIMICROBIAL ACTIVITY OF EXTRACTS OF TIBOUCHINA CANDOLLEANA (MELASTOMATACEAE), ISOLATED COMPOUNDS AND SEMI-SYNTHETIC DERIVATIVES AGAINST ENDODONTIC BACTERIA
}

\author{
Fernanda M. dos Santos, Maria Gorete de Souza, Antônio E. Miller Crotti, Carlos H. G. Martins, Sérgio R. Ambrósio, \\ Rodrigo C. S. Veneziani, Márcio L. Andrade e Silva, Wilson R. Cunha*
}

Núcleo de Pesquisa em Ciências Exatas e Tecnológicas da Universidade de Franca, Franca, SP, Brasil.

Submitted: August 18, 2011; Approved: March 05, 2012.

\begin{abstract}
This work describes the phytochemical study of the extracts from aerial parts of Tibouchina candolleana as well as the evaluation of the antimicrobial activity of extracts, isolated compounds, and semi-synthetic derivatives of ursolic acid against endodontic bacteria. HRGC analysis of the $n$-hexane extract of $T$. candolleana allowed identification of $\beta$-amyrin, $\alpha$-amyrin, and $\beta$-sitosterol as major constituents. The triterpenes ursolic acid and oleanolic acid were isolated from the methylene chloride extract and identified. In addition, the flavonoids luteolin and genistein were isolated from the ethanol extract and identified. The antimicrobial activity was investigated via determination of the minimum inhibitory concentration (MIC) using the broth microdilution method. Amongst the isolated compounds, ursolic acid was the most effective against the selected endodontic bacteria. As for the semi-synthetic ursolic acid derivatives, only the methyl ester derivative potentiated the activity against Bacteroides fragilis.
\end{abstract}

Key words: Tibouchina candolleana, ursolic acid, antimicrobial activity

\section{INTRODUCTION}

The periodontal disease is described as a set of inflammatory and infectious processes that attack the periodontal tissues. The inflammatory process is triggered mainly by Gram negative anaerobic bacteria. Adjuvant drug therapies have played a key role in assisting in cases involving development or persistence of infection during or after prescription of appropriate endodontic therapy (3).
Chemical agents have been employed, in order to promote bacteria eradication. Nevertheless, the different susceptibilities exhibited by oral pathogens, as well as the toxicity and allergenicity displayed by these chemicals, have made treatment very difficult $(13,20,21,29)$. This scenario illustrates the need for discovering new compounds that can be used as complement to instrumental procedures.

Plant species are an excellent source for the discovery of new antimicrobial drugs, mainly considering that the molecular

\footnotetext{
*Corresponding Author. Mailing address: Núcleo de Pesquisa em Ciências Exatas e Tecnológicas da Universidade de Franca, Av. Dr. Armando Salles de Oliveira 201, Parque Universitário, 14404-600, Franca, SP, Brazil.; Tel.: +55-16-37118878.; E-mail: wrcunha@unifran.br
} 
diversity of natural products is much higher than that derived from chemical syntheses. This fact has stimulated investigation of the antimicrobial activity of different plant extracts, in order to promote the development of new pharmaceuticals that can control many diseases such as oral diseases. In this context, our research group has recently concentrated efforts on the assessment of the antimicrobial properties of natural products from plants, aiming to detect new compounds that display antibacterial activity against oral pathogens and that can be employed as adjuvant therapy in dentistry $(4,6,9,26,27)$.

The genus Tibouchina, belonging to the Melastomataceae, is mainly distributed in tropical and subtropical regions of the Americas and includes about 350 species (25). In Brazil, Tibouchina species are known as "quaresmeira" and are used as ornamental plants because of their dark purple flowers. Previous studies on Tibouchina species have evidenced the presence of tannins, flavonoids, and benzoquinones (5,14,30,34-36). Crude plant extracts from Tibouchina and their isolated compounds have been reported to exhibit antioxidant and antifungal activities $(16,22,23)$. However, to the best of our knowledge, there is no previous report on Tibouchina candolleana. This has led us to investigate the phytochemical and the antimicrobial activity of the aerial parts of this plant.

\section{MATERIALS AND METHODS}

\section{Plant Material}

T. candolleana (Mart. ex DC.) Cogn. was collected in Peixoto (Minas Gerais, Brazil), near Usina Mascaranhas de Moraes, in September, 2003. The plant was identified by Dr. Angela Borges Martins, Instituto de Biologia, UNICAMP, Brazil. A voucher specimen (UEC 142048) has been deposited in the Herbarium of the same Institute.

\section{Extraction and Fractionation}

The aerial parts of $T$. candolleana were air-dried at $40^{\circ} \mathrm{C}$ and ground. The powdered material $(1.0 \mathrm{~kg})$ was exhaustively extracted by maceration at room temperature using $n$-hexane, methylene chloride, and ethanol, in this sequence, to afford the crude extracts (10.0 g, $15.5 \mathrm{~g}$, and $44.3 \mathrm{~g}$, respectively).

An aliquot of the $n$-hexane extract $(500 \mathrm{mg})$ was filtered over a Celite/Norit 3:1 w/w mixture $(60 \mathrm{~g})$ and eluted with ethyl acetate. An aliquot $(10 \mathrm{mg})$ of the resulting fraction was resuspended in chloroform $(3 \mathrm{~mL})$ and percolated through a sep-Kap column (Alltech, silica gel $200 \mathrm{mg}, 3 \mathrm{~mL}$ ). The column was eluted with chloroform $(10 \mathrm{~mL})$ and evaporated to dryness at room temperature, followed by HRGC analysis.

A sample of the methylene chloride extract $(10.0 \mathrm{~g})$ was chromatographed over silica gel 60 (300 g, 0.063-0.200 mm, Merck) using different solvents and vacuum liquid chromatography, which furnished five fractions of $1000 \mathrm{~mL}$ each (F1: $n$-hexane; F2: methylene chloride; F3: methylene chloride/AcOEt 50:50 v/v; F4: AcOEt; F5: EtOH). Fraction F3 $(4.53 \mathrm{~g})$ exhibited the highest antimicrobial activity, so part of this fraction $(1.50 \mathrm{~g})$ was filtered through a mixture of a Celite/Norit 3:1 w/w mixture (60 g) and eluted with AcOEt, which afforded a mixture containing ursolic acid and oleanolic acid $730 \mathrm{mg}$ ). These compounds were separated by HPLC, yielding ursolic acid (1) and oleanolic acid (2) as white amorphous solids $\left(\mathrm{R}_{\mathrm{t}}\right.$ : $20.67 \mathrm{~min}$ and $\mathrm{R}_{\mathrm{t}}$ : $21.52 \mathrm{~min}$, respectively) (15).

A sample of the ethanolic extract $(13.0 \mathrm{~g})$ was chromatographed over silica gel 60 (300 g, 0.063-0.200 mm, Merck) by vacuum liquid chromatography using different solvents, giving six fractions of $1000 \mathrm{~mL}$ each (Fr1: $n$ hexane/AcOEt 75:25 v/v ; Fr2: $n$-hexane/AcOEt 50:50 v/v; Fr3: AcOEt ; Fr4: AcOEt/EtOH 75:25 v/v ; Fr5: AcOEt/EtOH 50:50 v/v; Fr6: EtOH). Fraction Fr-3 (300 mg) was chromatographed over Sephadex LH-20 using methanol as eluent, followed by semi-preparative reverse-phase HPLC purification using methanol/ $\mathrm{H}_{2} \mathrm{O}(75: 25 \mathrm{v} / \mathrm{v})$ as mobile phase, to give rise to luteolin (3) (28 mg) and genistein (4) (15 mg).

\section{Preparation of C-3 ester derivatives of ursolic acid}

In order to obtain some triterpene acid derivatives, ursolic 
acid (20 mg) was treated with excess acetic anhydride in pyridine (11), to furnish the 3-acetoxyl derivative (15 mg) (1a). Ursolic acid (50 mg) was also treated with appropriate longchain fatty acids (44 mg lauric acid or $62.6 \mathrm{mg}$ stearic acid), $N, N^{\prime}$-dicyclohexylcarbodiimide (DCC, $113.5 \mathrm{mg}$ ), and 4dimethylamino-pyridine (DMAP, $67 \mathrm{mg}$ ) in 1,2dichloroethane. The reaction mixture was stirred at room temperature for $24 \mathrm{~h}$, which was followed by filtration and evaporation under reduced pressure (18). The residue was purified by silica gel column chromatography with $n$-hexane, to afford the corresponding fatty acid esters $1 \mathrm{~b}(35 \mathrm{mg})$ and $1 \mathrm{c}$ (38 mg).

\section{Preparation of the C-28 methyl ester derivative of ursolic acid}

Ursolic acid (20 mg) was treated with $\mathrm{CH}_{2} \mathrm{~N}_{2}$ in $\mathrm{Et}_{2} \mathrm{O}$ (11), yielding the respective $\mathrm{C}-28$ methyl ester derivative $1 \mathrm{~d}$ (18 $\mathrm{mg})$, which was purified by column chromatography on silica gel 60 (0.063-0.200 mm, Merck, Darmstadt, Germany).

\section{Structural Identification}

The structural elucidation of the isolated compounds was performed on the basis of MS as well as ${ }^{1} \mathrm{H}$ and ${ }^{13} \mathrm{C}$ NMR spectroscopic and comparison with published data. ${ }^{1} \mathrm{H}(400$ $\mathrm{MHz})$ and ${ }^{13} \mathrm{C}(100 \mathrm{MHz}) \mathrm{NMR}$ spectra were recorded on a Brüker DPX-400 spectrometer. Samples were dissolved in DMSO- $\mathrm{d}_{6}$ or $\mathrm{CDCl}_{3}$ using TMS as internal standard. Highresolution ESI-MS spectra were registered on a Bruker UltroTOF mass spectrometer.

\section{Gas chromatography analysis}

A portion $(50 \mathrm{mg})$ of the $T$. stenocarpa $n$-hexane extract was cleaned up and submitted to HRGC analysis according to a previously reported methodology (8). HRGC analysis was performed on a Hewlett-Packard model 5980 series II gas chromatograph equipped with a split injector (split ratio 1:60) operating at $260^{\circ} \mathrm{C}$ and a flame ionization detector operating at $330^{\circ} \mathrm{C}$. The injected volume was $2 \mu \mathrm{L}$. HP-50 (cross-linked $50 \%$ phenyl-methyl-silicone, $30 \mathrm{~m} \times 0.25 \mathrm{~m} \mathrm{x} 0.25 \mu \mathrm{m})$ and HP-1 (cross-linked methyl-silicone, $30 \mathrm{~m}$ x $0.25 \mathrm{~m}$ x $0.25 \mu \mathrm{m}$ ) capillary columns were employed. Hydrogen was used as the carrier gas at an average linear velocity of $44 \mathrm{~cm} . \mathrm{s}^{-1}$. Data were processed on a Hewlett-Packard model 3395 integrator.

\section{Determination of the antimicrobial activity}

The minimum inhibitory concentration (MIC) values of the samples were determined in triplicate by using the broth microdilution method in 96-well microplates (7). The tested strains were obtained from the American Type Culture Collection (ATCC). The following microorganisms were employed: Bacteroides fragilis (ATCC 25285), Actinomyces naeslundii (ATCC 19039), Porphyromonas gingivalis (ATCC 33277), Prevotella nigrescens (ATCC 33563), Fusobacterium nucleatum (ATCC 49256), Bacteriodes thetaiotaomicrom (ATCC 29741), and Peptostreptococcus anaerobius (ATCC 27337)

The samples were dissolved in DMSO at $1.0 \mathrm{mg} \mathrm{mL}^{-1}$, followed by dilution in schaedler broth (DIFCO, MO, USA) supplemented with hemin $\left(5.0 \mu \mathrm{g} \mathrm{mL}^{-1}\right)$ and vitamin $\mathrm{K} 1(10 \mu \mathrm{g}$ $\mathrm{mL}^{-1}$ ); concentrations ranging from 400.0 to $0.25 \mu \mathrm{g} \mathrm{mL}^{-1}$ were achieved. The final DMSO content was $5 \%(\mathrm{v} / \mathrm{v})$, and this solution was used as negative control. The inoculum was adjusted for each organism, to yield a cell concentration of $5 \times$ $10^{5}$ colony forming units (CFU) $\mathrm{mL}^{-1}$, according to previously standardization by the Clinical Laboratory Standards Institute (7). One inoculated well was included, to allow control of the adequacy of the broth for organism growth. One noninoculated well, free of antimicrobial agent, was also included, to ensure medium sterility. Chlorhexidine dihydrochloride was utilized as positive control. The microplates (96-wells) were sealed with plastic film. The time necessary for growth was 96 hours for anaerobes incubated at $37{ }^{\circ} \mathrm{C}$ under appropriate gaseous conditions [anaerobic work station (Don Whitley Scientific, Bradford, UK), in an atmosphere of $5-10 \% \mathrm{H}_{2}, 10 \%$ 
$\mathrm{CO}_{2}$, and $\left.80-85 \% \mathrm{~N}_{2}\right]$. Resazurin $(30 \mu \mathrm{L})$ in aqueous solution $(0.02 \%)$ was then added to the microplates, to indicate microorganism viability (28). The MIC value was determined as the lowest concentration of the compound capable of inhibiting microorganism growth.

\section{RESULTS AND DISCUSSION}

Studies on Tibouchina species are scarce in the literature. This is the first time that $T$. candolleana has been investigated. Figure 1 brings the chemical structures of the compounds identified in $T$. candollena extracts. The $n$-hexane extract, analyzed by HRGC, allowed identification of the compounds $\beta$ sitosterol (5), $\beta$-amirina (6), and $\alpha$-amirina (7).
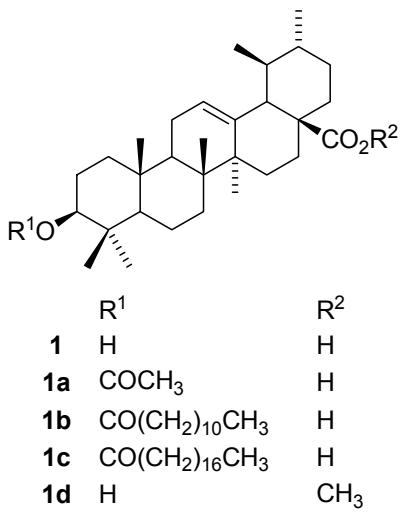<smiles>O=c1cc(-c2ccc(O)c(O)c2)oc2cc(O)cc(O)c12</smiles>

3

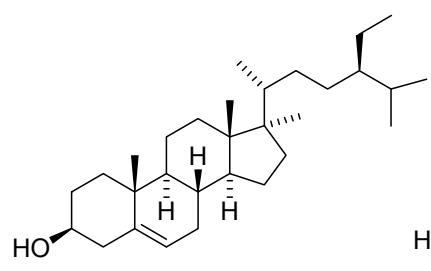

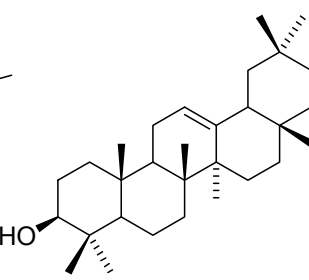

6
The NMR- ${ }^{1} \mathrm{H}$ and ${ }^{13} \mathrm{C}$ data of fraction $\mathrm{F}-2$, obtained from fractionation of the methylene chloride extract, revealed the presence of a mixture of ursolic and oleanoic acids (12). This fraction was further chromatographed by HPLC, which enabled isolation of ursolic acid (1) and oleanolic acid (2) (Figure 1). Both acids consist of triterpenoids that are widely distributed in the plant kingdom, and they have been frequently isolated from other species belonging to Melastomataceae family as mutually isomeric mixtures $(10,11,31)$. However, this is the first time that ursolic acid and oleanolic acid have been reported in this genus. These triterpene acids display several biological activities (17).

In addition, fractionation of the ethanolic extract allowed isolation and identification of the flavonoids luteolin (3) (33) and genistein (4) (24) (Fig. 1).

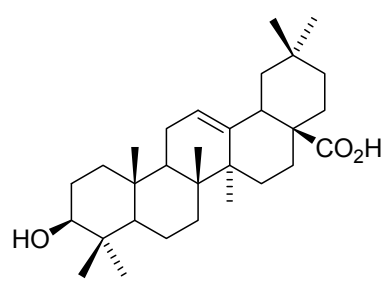

2<smiles>O=c1c(-c2ccc(O)cc2)coc2cc(O)cc(O)c12</smiles>

4

Figure 1. Chemical structures of compounds present in Tibouchina candolleana extracts and of semi-synthetic derivatives. 
Regarding the effects of the $T$. candollena extracts on the growth of the selected endodontic bacteria, all crude extracts exhibited low antimicrobial activity, as shown in Table 1.

Amongst the compounds evaluated in the present work, the mixture of ursolic and oleanolic acids $(1+2)$ was the most active against Bacteroides fragilis, with a MIC value of $20 \mu \mathrm{g}$ $\mathrm{mL}^{-1}$. The mixture was more active than pure ursolic acid (MIC $=80 \mu \mathrm{g} \mathrm{mL}^{-1}$ ), indicating a possible synergistic effect. The mixture 1+2 was also effective against Actinomyces naeslundii and Porphyromonas gingivalis, with MIC values of $20 \mu \mathrm{g} \mathrm{mL}$ and $40 \mu \mathrm{g} \mathrm{mL}^{-1}$, respectively.
Ursolic acid (1) was the most effective against most of the tested bacteria, with MIC values of $20 \mu \mathrm{g} \mathrm{mL}^{-1}$ for Actinomyces naeslundii and Porphyromonas gingivalis, $80 \mu \mathrm{g} \mathrm{mL} \mathrm{m}^{-1}$ for Bacteroides fragilis, and $90 \mu \mathrm{g} \mathrm{mL}^{-1}$ for Prevotella nigrescens. Oleanolic acid (2) also afforded significant results for the strains Actinomyces naeslundii and Porphyromonas gingivalis, with MIC values of $20 \mu \mathrm{g} \mathrm{mL}^{-1}$ and $40 \mu \mathrm{g} \mathrm{mL}^{-1}$, respectively.

The flavonoids genistein (3) and luteolin (4) were not satisfactorily active against the investigated bacteria tested, since MIC values higher than or equal to $400 \mu \mathrm{g} \mathrm{mL}^{-1}$ were achieved.

Table 1. Minimum inhibitory concentration values $\left(\mu \mathrm{g} \mathrm{mL}^{-1}\right)$ obtained for the crude extracts of Tibouchina candolleana, isolated compounds, and semi-synthetic derivatives.

\begin{tabular}{|c|c|c|c|c|c|c|c|}
\hline \multirow[b]{2}{*}{ Samples } & \multicolumn{7}{|c|}{ Microorganisms } \\
\hline & $\begin{array}{c}\text { Bacteroides } \\
\text { fragilis }\end{array}$ & $\begin{array}{c}\text { Actinomyces } \\
\text { naeslundii }\end{array}$ & $\begin{array}{c}\text { Porphyromonas } \\
\text { gingivalis }\end{array}$ & $\begin{array}{l}\text { Prevotella } \\
\text { nigrescens }\end{array}$ & $\begin{array}{c}\text { Fusobacterium } \\
\text { nucleatum }\end{array}$ & $\begin{array}{c}\text { Bacteroides } \\
\text { thetaiotaomicron }\end{array}$ & $\begin{array}{c}\text { Peptostreptococcus } \\
\text { anaerobius }\end{array}$ \\
\hline${ }^{\mathrm{a}}$ Hex & $>400$ & $>400$ & $>400$ & $>400$ & $>400$ & $>400$ & $>400$ \\
\hline${ }^{\mathrm{b}} \mathrm{MC}$ & $>400$ & $>400$ & $>400$ & $>400$ & $>400$ & $>400$ & $>400$ \\
\hline${ }^{\mathrm{c}} \mathrm{EtOH}$ & $>400$ & 400 & $>400$ & $>400$ & $>400$ & $>400$ & $>400$ \\
\hline 1 & 80 & 20 & 20 & 90 & $>400$ & $>400$ & 200 \\
\hline 2 & $>400$ & 20 & 40 & 200 & $>400$ & $>400$ & 400 \\
\hline $1+2$ & 20 & 20 & 40 & 300 & 400 & $>400$ & 400 \\
\hline 3 & $>400$ & 400 & 400 & 400 & $>400$ & $>400$ & $>400$ \\
\hline 4 & $>40$ & $>400$ & $>400$ & $>400$ & $>400$ & $>400$ & 400 \\
\hline $1 \mathrm{a}$ & $>400$ & $>400$ & $>400$ & $>400$ & $>400$ & $>400$ & 400 \\
\hline $1 b$ & $>400$ & $>400$ & $>400$ & $>400$ & 400 & $>400$ & 400 \\
\hline $1 \mathrm{c}$ & $>400$ & $>400$ & $>400$ & $>400$ & 400 & $>400$ & 400 \\
\hline $1 d$ & $>400$ & 200 & $>400$ & 300 & 400 & 400 & 400 \\
\hline $\begin{array}{l}{ }^{\mathrm{d}} \text { Positive } \\
\text { Control }\end{array}$ & 14.8 & 7.4 & 3.7 & 3.7 & 14.8 & 29.0 & 7.4 \\
\hline
\end{tabular}

${ }^{\mathrm{a}} n$-hexane extract; ${ }^{\mathrm{b}}$ methylene chloride extract; ${ }^{\mathrm{c}}$ ethanolic extract

${ }^{\mathrm{d}}$ Positive control: chlorhexidine

According to several authors $(3,32)$, drugs derived from natural products can serve not only as new drugs themselves, but also as lead compounds for chemical modifications that could furnish derivatives with better activity and pharmacokinetic properties, new mechanisms of action, and fewer adverse side effects. In an effort to obtain more active compounds, semi-synthetic derivatives of ursolic acid $(1 \mathrm{a}-1 \mathrm{~d})$ were prepared (Figure 1). Mallavadhani and co-workers (19) have demonstrated that lipophilicity is an important parameter in the development of biological agents. The authors stated that molecules with carbon chains above C-10 are fairly lipophilic and consequently good candidates for pharmacological assessment. In view of these observations, two lipophilic 3-Ofatty acid ester chain derivative of ursolic acid (1b and 1c) were synthesized herein. The $3 \beta$-dodecanoate $(1 \mathrm{~b})$ and the $3 \beta$ octadecanoate (1c) derivatives of ursolic acid did not promote lower MIC values against any of the studied microorganisms. The difference in outcomes may be related to the types of 
bacteria used in the several literature works, and the mechanisms involved in the activity are probably different.

The presence of the 3-acetoxy group in derivative 1a did not enhance the bactericide activity as compared to ursolic acid, while the C-28 methyl ester derivative (1d) had improved the activity against Bacteroides fragilis only, with a MIC value of $20 \mu \mathrm{g} \mathrm{mL}^{-1}$. Thus, comparison between the MIC values of ursolic acid and those of its semi-synthetic derivatives suggests that the $\mathrm{COOH}$ and $\mathrm{OH}$ groups attached to carbons 3 and 17 , respectively, are important for the activity against these bacteria.

In summary, our study indicates promising results for the antimicrobial activity of ursolic acid (1) and oleanolic acid (2) against some endodontic bacteria. It has been reported that these compounds are not toxic $(1,18)$, which makes them particularly interesting for future developments of novel antimicrobial agents against endodontic bacteria.

It is also important to emphasize that in view of the promising results obtained for these compounds, other biological studies to elucidate the mechanism of antimicrobial action as well as the structure-activity relationship are necessary. In this context, additional antimicrobial studies to detail the kinetics, synergistic activities, and mode of action of such compounds must also be conducted, so that better understanding of their characteristics and potential can be gained.

\section{ACKNOWLEDGEMENTS}

The authors are grateful to FAPESP, CAPES, and CNPq for financial support. The authors also thank Dr Angela Borges Martins (Universidade Estadual de Campinas) for plant identification.

\section{REFERENCES}

1. Andrade, S.F.; Da Silva Filho, A.A.; Resende, D.O.; Silva, M.L.A.; Cunha, W.R.; Nanayakkara, N.P.D.; Bastos, J.K. (2008). Antileishmanial, antimalarial and antimicrobial activities of the extract and isolated compounds from Austroplenckia populnea (Celastraceae). Z. Naturforsch. 63c 497-502.

2. Bakri, I.M.; Douglas, C.W.I. (2005). Inhibitory effect of garlic extract on oral bacteria. Arch. Oral Biol. 50 (7), 645-651.

3. Balunas, M.J.; Kinghorn, A.D. (2005). Drug discovery from medicinal plants. Life Sci. 78 (5), 431-441.

4. Bernardes, W.A.; Lucarini, R.; Tozatti, M.G.; De Souza, M.G.; Silva, M.L.A.; Da Silva Filho, A.A.; Martins, C.H.G.; Crotti, A.E.M.; Pauletti, P.M.; Groppo, M.; Cunha, W.R. (2010). Antimicrobial activity of Rosmarinus officinalis against oral pathogens: the relevance of carnosic acid and carnosol. Chem. Biodiver. 7 (7), 1835-1840.

5. Bobbio, F.O.; Bobbio, P.A.; Degáspari, C.H. (1985). Anthocyanins from Tibouchina grandflora. Food Chem. 18 (2), 153-159.

6. Carvalho, T.C.; Simão, M.R.; Ambrósio, S.R.; Furtado, N.A.J.C.; Veneziani, R.C.S.; Heleno, V.C.G.; Da Costa, F.B.; Gomes, B.P.F.A.; Souza, M.G.M.; Dos Reis, E.B.; Martins, C.H.G. (2011). Antimicrobial activity of diterpenes from Viguiera arenaria against endodontic bacteria. Molecules 16 (1), 543-551.

7. CLSI. Clinical and Laboratory Standards Institute (2007). CLSI document M11-A7. Methods for antimicrobial susceptibility testing of anaerobic bacteria. Approved Standard, 7th ed. CLSI: Wayne, PA.

8. Crevelin, E.J.; Turatti, I.C.C.; Crotti, A.E.M.; Veneziani, R.C.S.; Lopes, J.L.C.; Lopes, N.P.; Cunha, W.R. (2006). Identification of biologically active triterpenes and sterols present in hexane extracts from Miconia species using high resolution gas chromatography. Biom. Chromatogr. $20(8), 827-820$.

9. Cunha, L.C.S.; Silva, M.L.A.; Furtado, N.A.J.C.; Vinhólis, A.H.C.; Martins, C.H.G.; Da Silva Filho, A.A.; Cunha, W.R. (2007). Antibacterial activity of triterpene acids and semi-synthetic derivatives against oral pathogens. Z. Naturforsch. C 62 (9), 668-672.

10. Cunha, W.R.; Crevelin, E.J.; Arantes, G.M.; Crotti, A.E.M.; Silva, M.L.A.; Furtado, N.A.J.C.; Albuquerque, S.; Ferreira, D.S. (2006). A study of the trypanocidal activity of triterpene acids isolated from Miconia species. Phytother. Res. 20 474-478.

11. Cunha, W.R.; Martins, C.; Ferreira, D.S.; Crotti, A.E.M.; Lopes, N.P.; Albuquerque, S. (2003). In vitro trypanocidal activity of triterpenes from Miconia species. Planta Med. 69 470-472.

12. Cunha, W.R.; Martins, C.H.G.; Ferreira, D.S.; Crotti, A.E.M.; Lopes, N.P.; Albuquerque, S. (2003). In vitro trypanocidal activity of triterpenes from Miconia species. Planta Med 69 (5), 470-472.

13. Gomes, B.P.F.A.; Pinheiro, E.T.; Gade-Neto, C.R.; Sousa, E.L.R.; Ferraz, C.C.R.; Zaia, A.A.; Teixeira, F.B.; Souza, F.J. (2004). Microbiological examination of infected dental root canals. Oral Microbiol. Immun. 19 (2), 71-76.

14. Jones, E.; Ekundayo, E.; Kingston, D. (1980). Anticancer agents XI. 2,6dimethoxybenzoquinone as a cytotoxic constituent of Tibouchina pulchra. J. Nat. Prod. 44 (4), 493-494. 
15. Kim, Y.K.; Yoon, S.K.; Ryu, S.Y. (2000). Cytotoxic triterpenes from stem bark of Physocarpus intermedius. Planta Med. 66 485-486.

16. Kuster, R.M.; Arnold, N.; Wessjohann, L. (2009). Anti-fungal flavonoids from Tibouchina grandifolia. Biochem. System. Ecol. 37 (1), 63-65.

17. Liu, J. (1995). Pharmacology of oleanolic acid and ursolic acid. J. Ethnopharmacol. 49 57-68.

18. Mallavadhani, U.V.; Mahapatra, A.; Jamil, K.; Reddy, P.S. (2004). Antimicrobial activity of some pentacyclic triterpenes and their synthesized 3-O-lipophilic chains. Biol. Pharm. Bull. 27 1576-1579.

19. Mallavadhani, U.V.; Mahapatra, A.; Jamil, K.; Reddy, P.S. (2004). Antimicrobial activity of some pentacyclic triterpenes and their synthesized 3-O-lipophilic chains. Biol. Pharm. Bull. 27 (10), 15761579 .

20. Mohammadi, Z.; Abbott, P.V. (2009). On the local applications of antibiotics and antibiotic based agentsin endodontics and dental traumatology. Int. Endod. J. 42 (7), 555-567.

21. Mohammadi, Z.; Abbott, P.V. (2009). The properties and applications of chlorhexidine in endodontics. Int. Endod. J. 42 (4), 288-302.

22. Mosquera, O.M.; Correa, Y.M.; Nino, J. (2009). Antioxidant activity of plant extracts from Colombian flora. Braz. J. Pharmacog. 19 (2A), 382 387.

23. Nino, J.; Espinal, C.M.; Mosquera, O.M.; Correa, Y.M. (2003). Antimycotic activity of 20 plants from Colombian flora. Pharm. Biol. 41 (7), 491-496.

24. Pelter, A.; Ward, R.S.; Bass, R.J. (1978). The carbon-13 nuclear magnetic resonance spectra of isoflavones. J. Chem. Soc. Perkin Trans. I $6(6), 666-688$.

25. Peralta, P. (2002). Las especies del género Tibouchina (Melastomataceae) em la Argentina. Darwiniana 40 (1-4), 107-120.

26. Porto, T.S.; Furtado, N.A.J.C.; Heleno, V.C.G.; Martins, C.H.G.; Da Costa, F.B.; Severiano, M.E.; Silva, N.A.; Veneziani, R.C.S.; Ambrósio, S.R. (2009). Antimicrobial ent-pimarane diterpenes from Viguiera arenaria against Gram-positive bacteria. Fitoterapia 80 (7), 432-436.

27. Porto, T.S.; Rangel, R.; Furtado, N.A.J.C.; De Carvalho, T.C.; Martins, C.H.G.; Veneziani, R.C.S.; Da Costa, F.B.; Vinholis, A.H.C.; Cunha,
W.R.; Heleno, V.C.G.; Ambrosio, S.R. (2009). Pimarane-type diterpenes: antimicrobial activity against oral pathogens. Molecules 14 (1), 191-199.

28. Sarker, S.D.; Nahar, L.; Kumarasamy, Y. (2007). Microtitre plate-based antibacterial assay incorporating resazurin as an indicator of cell growth, and its application in the in vitro antibacterial screening of phytochemicals. Methods 42 (4), 321-324.

29. Sathorn, C.; Parashos, P.; Messer, H. (2007). Antibacterial efficacy of calcium hydroxide intracanal dressing: a systematic review and metaanalysis. Int. Endod. J. 40 (1), 2-10.

30. Sirat, H.M.; Rezali, M.F.; Ujang, Z. (2010). Isolation and identification of radical scavenging and tyrosinase inhibition of polyphenols from Tibouchina semidecandra L. J. Agric. Food Chem. 58 (19), $10404-$ 10409.

31. Vasconcelos, M.A.L.; Royo, V.A.; Ferreira, D.S.; Crotti, A.E.M.; Silva, M.L.A.; Carvalho, J.C.T.; Bastos, J.K.; Cunha, W.R. (2006). In vivo analgesic and anti-inflammatory activities of ursolic acid and oleanoic acid from Miconia albicans (Melastomataceae). Z. Naturforsch. 61c 477486.

32. Vuorela, P.; Leinonen, M.; Saikku, P.; Tammela, P.; Rauha, J.P.; Wennberg, T.; Vuorela, H. (2004). Natural products in the process of finding new drug candidates. Curr. Med. Chem. 11 (11), 1375-1389.

33. Wawer, I.; Zielinska, A. (2001). 13C CP/MAS NMR studies of flavonoids. Magn. Reson. Chem. 39 (1-2), 374-380.

34. Yoshida, T.; Amakura, Y.; Yokura, N.; Ito, H.; Isaza, J.H.; Ramirez, S.; Pelaez, D.P.; Renner, S.S. (1999). Oligomeric hydrolyzable tannins from Tibouchina multiflora. Phytochemistry 52 (8), 1661-1666.

35. Yoshida, T.; Nakata, F.; Okuda, T. (1999). Tannins and related polyphenols of Melastomataceous plants VIII. Nobotanins L, M. and N, trimeric hydrolyzable tannins from Tibouchina semicandra. Chem. Pharm. Bull. 47 (6), 824-827.

36. Yoshida, T.; Ohbayashi, H.; Ishihara, K.; Ohwashi, W.; Haba, K.; Okano, Y.; Shingu, T.; Okuda, T. (1991). Tannins and related polyphenols of Melastomataceous plants I. Hydrolyzable tannins from Tibouchina semidecandra Cogn. Chem. Pharm. Bull. 39 (9), 2233-2240. 